\title{
PROFESSIONALISM
}

\section{University Teacher Educators' Professional Agency: A Literature Review}

\section{Yenny Hinostroza-Paredes}

University of Helsinki, Finland

Contact: Yenny Hinostroza-Paredes, University of Helsinki, Finland, yenny.hinostrozaparedes@helsinki.fi

\section{Abstract}

This paper presents a scoping review and thematic analysis of literature on university teacher educators' professional agency between 2007 and 2019. Its aim is to map empirical studies to date and identify gaps in research to inform a future research agenda. 28 articles that met the inclusion criteria were subjected to thematic analysis, using line-by-line open and axial coding. Four main interrelated themes were identified: (i) education policies, (ii) professional development, (iii) identity, and (iv) social justice. This thematic intersection reflects intricated factors promoting and hindering the achievement of teacher educators' professional agency. Findings suggest that more research is needed to develop theoretical and empirical understandings of the multidimensional character of their professional agency, and the myriad of opportunities and constraints impacting on it.

\section{Keywords}

Agency, professional development, identity, social justice, educational policies

\section{Introduction}

Over the last two decades, the critical but increasingly demanding role of teacher educators (TEs) in preparing quality teachers has received growing attention (Ben-Peretz, 2001). Extensive research on TEs' professional development, transition to academia, identity, 
pedagogical beliefs and attitudes has deepened our understanding of their profession (Cochran-Smith, 2003; Davey, 2013; Ipkeze, 2016; Isotalo, 2017). And while some overviews cover specific subject TEs, and themes of professional identity, self-study practices, and professional learning (Izadinia, 2014; McEvoy, MacPhail \& Heikinaro-Johansson, 2015; Ping, Schellings \& Beijaard, 2018; Vanassche \& Kelchtermans, 2015), noticeably absent is a synthesis of knowledge on their professional agency at work. Given the current debates on the effects of dominant neoliberal education policies upon initial teacher education (ITE) and TEs' professionalism across countries (Clarke \& McFlynn, 2019; Cobb \& Couch, 2018), mapping out the central themes of scholarly literature on their professional agency may contribute to illuminate the complexity of their work, and inform future research and policy agendas.

The notion of agency has been widely discussed in sociological (Archer, 2003; Giddens, 1984), psychological (Bandura, 2001; Vygotsky, 1978) and educational studies literature (Lipponen \& Kumpulainen, 2011; Priestley, Biesta \& Robinson, 2015), illustrating the variety of perspectives and possibilities for its research. Similarly, notions of professional agency have been drawn from a social justice approach (Pantić \& Florian, 2015), a subject-centered sociocultural perspective (Eteläpelto, Vähäsantanen, Hökkä \& Paloniemi, 2013) or a lifecourse viewpoint (Emirbayer \& Mische, 1998). Therefore, my approach to this literature review was recognizing that multiple forms of agency-individual, collective, strong, weak, agency-as-resistance - could be identified and achieved in any given situation. By doing so, a more thorough comprehension of its fluid, contextual and temporal nature (Forsman, Collin \& Eteläpelto, 2014) may be gained.

But to understand TEs' agency, then their professional heterogeneity needed consideration. They may come from varied professional backgrounds, adopt multiple roles-second-order teachers, gatekeepers, curriculum developers, researchers-and work in diverse settings, such as higher education (HE) or schools (Lunenberg, Dengenrink \& Korthagen, 2014). Because university- and school-based TEs greatly differ from each other, specifically regarding qualifications, professional roles and expectations from their workplaces (White, Dickerson \& Weston, 2015), the study was limited to TEs located in HE institutions.

The reasons for conducting a scoping review are to (1) describe the extent and nature of existing published research; (2) evaluate undertaking a systematic review; (3) summarize and disseminate research findings; and (4) identify existing gaps in research (Arksey \& O'Malley, 2005). The aim of this study was aligned to reasons one, three and four. That was, to map the current literature on TEs' professional agency and identify any research gaps to inform a future research agenda. Since research questions in scoping reviews should be broad, focusing on synthesizing the breadth of literature (Arksey \& O'Malley, 2005), the overarching research question was: 
RQ1: What is known from the existing literature about the factors involved in the achievement of university teacher educators' professional agency at work?

Accordingly, key concepts on human and professional agency are introduced first. Then, the chosen methodological approach is explained. Once presented the findings from the descriptive overview and thematic analysis, they and their implications for future research are discussed. Finally, conclusions are drawn with recommendations for researchers, TEs and relevant stakeholders.

\section{Defining key concepts}

Diverse conceptualizations of agency emerge across disciplines. In cultural studies, it is individuals' socially constructed capacity to act, neither totally governed by free will nor completely determined by social structure (Barker, 2003). In social theory, Archer (2003) sees agency as conditioned by social structure and the result of individuals' reflexivity or deliberative "internal conversations." Through reciprocal relations, collective reflexivity supports corporate agency that is characterized by "articulating shared interests, organising for collective action, generating social movements and exercising corporate influence in decision-making" (Archer, 2000, p. 266). In lifecourse theory, Emirbayer \& Mische (1998, p. 971) view agency as a chordal triad with three dimensions corresponding to three different temporal orientations (past, future, present). These temporal orientations are always simultaneously present, but one of them dominates at a given time, determining whether the structures within which the individual operates are transformed or reproduced. Following Emirbayer \& Mische (1998), the ecological approach sees agency caught between past and future; it is a "dialogical process by and through which actors immersed in temporal passage engage with others within collectively organised contexts-for-action" (Biesta \& Tedder, 2007, p. 136). Therefore, it is not a capacity that individuals have, but something that they can do or achieve under certain ecological conditions (Biesta \& Tedder, 2007, p. 137). In psychology, agency is the ability to act intentionally-either individually or collectively - with collective agency being deliberate efforts to achieve a desired outcome through group action (Bandura, 2001). In sociocultural theory, rather than a trait or activity, human agency is a contextually enacted way of being in the world, mediated by psychological and technical tools, such as language or computers (Vygotsky, 1978). In poststructural theory, agency cannot exist outside discourse, lying in the dynamic interaction between power and resistance (Foucault, 1980, p. 95). Consistent with ideas of liberal capitalism, the neoliberal view of agency regards individuals as a flexible bundle of skills, which they are supposed to commoditize, and where the "self is run like a business" (Gershon, 2011, p. 546). Neoliberal agents accumulate and improve skills continuously, and trade them in business relationships that are assumed morally and socially uniform (Gershon, 2011). 
Conceptualizations on agency have also extended to professions. Grounded on activity theory, relational agency refers to individuals' capacity of working with others, negotiating and integrating professional knowledge to serve shared goals, leading to an enhanced form of professional agency (Edwards, 2005). Here the focus is on social collaboration rather than individuals' autonomy. From a subject-centered sociocultural perspective, professional agency is the subjects' capability for making choices, using discretional opportunities that allow them to affect their work and negotiate professional identity (Eteläpelto et al., 2013). Here, professional identity is the set of attributes, beliefs, values, motives and experiences through which individuals define themselves in a professional role (Ibarra, 1999). Aligned with the ecological approach, teachers' professional agency emerges from the interplay of individual capacities and social, material and temporal environments (Priestley et al., 2015). It entails the capacity to negotiate the conditions and content of their work, impacting educational change processes; teacher agency is strong when they actively influence working practices meaningful to them, and weak when they lack opportunities to do so (Hökkä \& Vähäsantanen, 2014, p. 5). Even without controlling the construction and direction of reform, teachers can achieve reserved or progressive agency when evaluating and deciding on how to deal with it. If the former implies high resistance and the performance of the minimum required activities, the latter involves teachers' active, innovative and approving engagement with change (Vähäsantanen, 2015). Inextricably linked, teacher identity influences the achievement of teacher agency while activated and sustained by it (Wilson \& Deaney, 2010). Moreover, both are vital components of teacher professional development, seen as the ongoing reshaping of their professional identities on coherently positive lines, and the continuous strengthening of professional agency (Alvesson, Ashcraft \& Thomas, 2008).

Concerning TEs, their professional agency is the "capacity to meaningfully construct and display their professional identity within socially defined contexts; in other words, their capacity to (re)negotiate their professional identities within their local work practices" (Hökkä, Eteläpelto \& Rasku-Puttonen, 2012, p. 86). This definition acknowledges that TEs' social settings and working conditions frame their achievement of agency when crafting their professional identities. Within macro- and meso-structures of national education policies and institutional policy implementation, those conditions and settings are currently saturated with managerial logics of neoliberal agency, austerity, digitalization, labor precariousness, and collegiality imposed "from above" (Avis \& Reynolds, 2018; Samuelsson, 2018). This situation is troublesome when TEs are committed to raising students' critical awareness of the systemic barriers to learning for all, and prepare them to teach for social justice, defined as the just distribution of rights, opportunities and resources for everyone in society (Ketschau, 2015).

Far from an exhaustive list, the notions of agency and professional agency above allow the recognition of their multiple forms (e.g., corporate, relational, strong or reserved). They 
encompass innovation and creativity but also resistance and rejection. Located and enabled by structural contexts as well as time-embedded, agency and professional agency emerge as continual reflexive processes to negotiate their own containments individually or through a web of relations with others. Adopting different modes, they are an essential resource for identity negotiations that, in the profession of TEs, can be mobilized by several factors, such as commitments to social justice, professional development or the discursive power of macro- or meso-structures. Thus, these factors and their intersections provide the necessary scene for different modes of TEs' professional agency to be achieved and are central in the studies included in this review.

\section{Methods}

Adopting the methodological conventions of a scoping review, this study surveys the literature on TEs' professional agency. This is an exploratory mode of knowledge synthesis that maps the extent of research in a given field, clarifies its key conceptual anchors, reveals existing literature gaps, and determines the feasibility of further research (Arksey \& O'Malley, 2005). Although a scoping review does not assess article quality as a systematic review does, its methodology requires similar systematic activities, being them constructing well-defined research questions, setting a clear search strategy, and embarking on analysis (descriptive numerical summary and qualitative thematic analysis) (Arksey \& O'Malley, 2005; Levac, Colquhoun \& O’Brien, 2010).

\section{Inclusion-Exclusion Criteria}

After an initial scan of the literature, the last 12-year period was determined because the observed increase of research on university TEs' agency, reflecting concerns regarding the transformations that neoliberal education policies brought to their working conditions. Then, the following inclusion criteria were set to include: (1) studies published between 2007 and 2019, (2) published in peer-reviewed journals, (3) English language publications, (4) specified methods for collection and analyses of TEs' data, (5) focused on TEs' professional agency. Accordingly, the exclusion criteria were: (1) not published in peerreviewed journals (PhD and Master's theses were excluded because of accessibility issues), (2) languages other than English, (3) research not employing any data collection or method (quantitative, qualitative or mixed-methods), (4) papers describing others than TEs at higher education institutions. Thus, data on university and college-based TEs were deemed relevant while school-based TEs were excluded. Heads of departments were not considered unless specified.

\section{Review Process}

The electronic databases searched for peer-reviewed literature were EBSCO, ERIC, SCOPUS, ScienceDirect, Springer Link, and Wiley Online Library. Key descriptors were sought in the papers' titles and abstracts: teacher educator(s) OR university teacher(s) OR professor of education OR university-based teacher educator AND agency OR agentic OR agency at work 
OR professional agency. Search limiters ensured the retrieval of only English-speaking articles published between 2007 and 2019. The initial search generated 1,033 references using the descriptors, from which 350 duplicates were removed. Following abstract reading of the resulting 683 papers, 216 were categorized as potentially relevant. Finally, these papers were retrieved and fully read considering the inclusion-exclusion criteria, and 16 studies were selected. The excluded 200 papers encompassed studies making a passing reference to TEs' agency; with no defined research methodology; commentaries, and nonempirical articles; and studies where TEs' data was unrecognizable from the one of other participants. A follow-up search in Google Scholar was also conducted to check for potentially missed articles, identifying another nine relevant studies. Later, a manual search of the reference list of the selected studies, alongside the content of all journals containing two or more relevant articles yielded another three papers. The scoping review included a total of 28 articles (Figure 1). All data extracted was then collated and summarized in an Excel template.

Data analysis involved a descriptive summary and thematic analysis, which is a method to examine the most significant constellations of meaning in the data set (Joffe, 2012). To familiarize with their data, all 28 papers were read several times and then uploaded to ATLAS.ti software for an inductive qualitative thematic synthesis in three stages (Thomas \& Harden, 2008). The first stage began with line-by-line coding to identify recurring words, concepts, and phrases of relevance to the research question. Next, after comparing codes across articles (axial coding), they were clustered into 17 descriptive sub-themes, according to content and meaning. Finally, similarities and differences among the sub-themes were grouped into four overarching themes. Throughout this iterative process of continuous interaction with the data and its analysis, themes did not change but sub-themes were constantly revised and refined. 


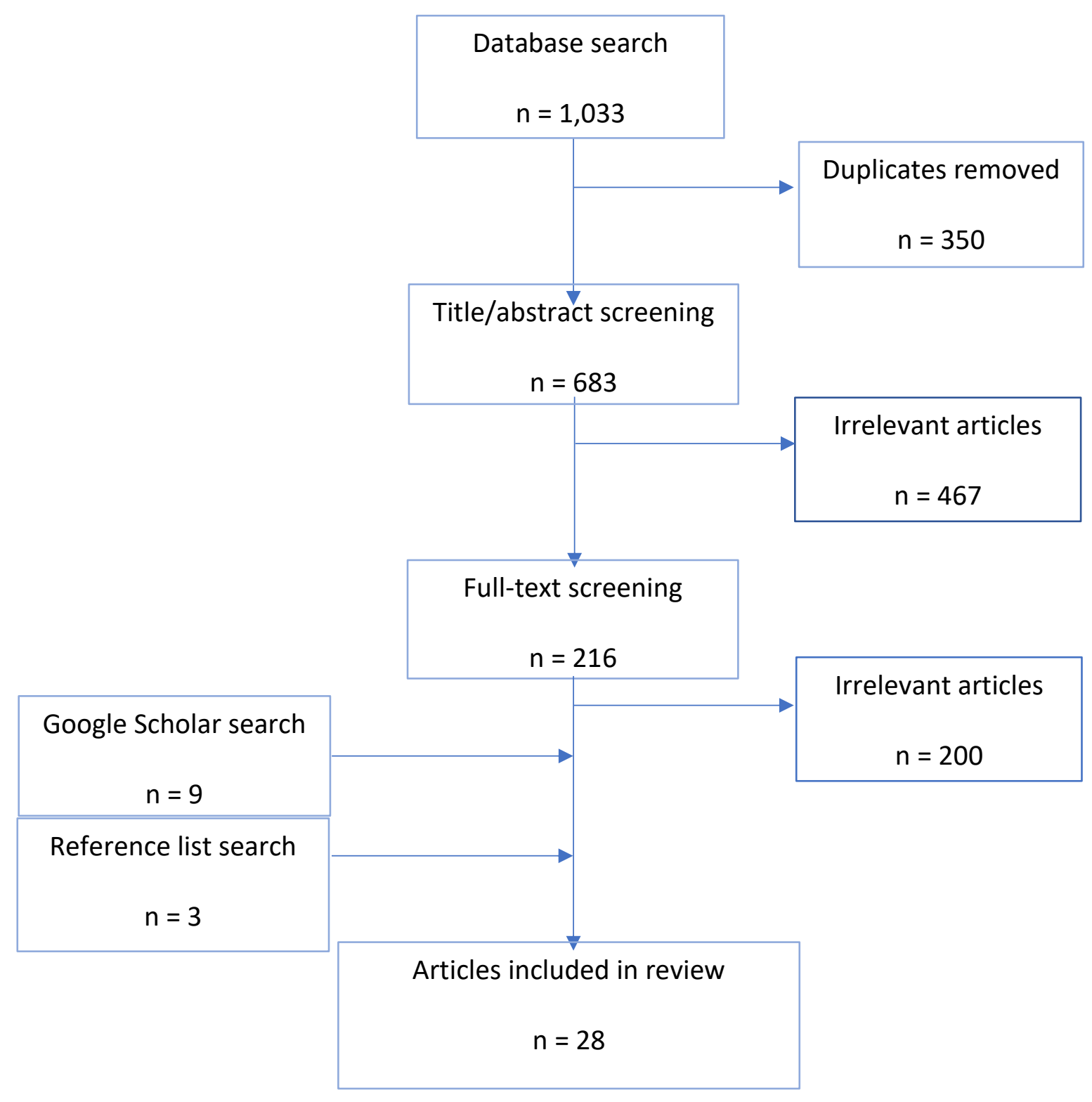

Figure 1. Scoping review flowchart

\section{Findings}

\section{Descriptive Overview}

Research was largely conducted in the USA and Western Europe $(n=18)$, with the remaining studies from Asia, Africa and Oceania $(n=10)$. Although with a fluctuating trend in the number of publications, the bulk of peer-reviewed literature concentrated between 2014 and 2019 (21 studies out of 28). Sample sizes ranged from one (self-study) to 23 participants. Qualitative methodology was prominent $(n=26)$, with the remaining studies being mixed-method $(n=2)$ (Table 1$)$. 
University Teacher Educators' Professional Agency

Table 1. Descriptive summary of the included studies

\begin{tabular}{|l|l|}
\hline Characteristic & Number \\
\hline Study type & \\
\hline Self-study & 3 \\
\hline Mixed methods & 2 \\
\hline Phenomenology & 5 \\
\hline Autoethnography & 3 \\
\hline Case study & 3 \\
\hline $\begin{array}{l}\text { Action research, intervention, mixed longitudinal, and } \\
\text { qualitative meta-analysis research }\end{array}$ & 4 \\
\hline Ethnography & \\
\hline Narrative research & 5 \\
\hline Study location & 3 \\
\hline The United States & \\
\hline Finland & 10 \\
\hline Australia & 4 \\
\hline South Africa & 4 \\
\hline Hong Kong & 2 \\
\hline The United Kingdom & 2 \\
\hline Pakistan & 2 \\
\hline The Netherlands & 1 \\
\hline Ireland & 1 \\
\hline China & 1 \\
\hline Publication year & 1 \\
\hline 2007 & \\
\hline 2011 & 1 \\
\hline 2012 & 1 \\
\hline 2013 & 2 \\
\hline 2014 & 3 \\
\hline 2015 & 8 \\
\hline 2016 & 1 \\
\hline 2017 & 2 \\
\hline 2018 & 3 \\
\hline 2019 & 5 \\
\hline & 2 \\
\hline & \\
\hline & \\
\hline & \\
\hline
\end{tabular}

\section{Thematic analysis}

Four salient, intertwined themes emerged from the data to answer the research question for this review (Table 2). Most of the 28 articles have a prominent theme that intersects with any of the others. Hence, education policies is an overarching theme present in most of the studies. And although an article may focus on professional development, it would also explore issues of professional identity or social justice (Table 3). 
University Teacher Educators' Professional Agency

Table 2. Codes, sub-themes and emerging themes

\begin{tabular}{|c|c|c|}
\hline Codes & Sub-themes & Themes \\
\hline $\begin{array}{l}\text { Professional standards* } \\
\text { Teacher performance assessment } \\
\text { Accreditation } \\
\text { Accountability } \\
\text { Resistance } \\
\text { Reinterpretation of standards } \\
\text { Compliance } \\
\text { Identity* } \\
\text { Make choices } \\
\text { Academic capital } \\
\text { Structure* } \\
\text { Self-study } \\
\text { Autoethnography* }\end{array}$ & $\begin{array}{l}\text { Neoliberal policies } \\
\text { Quality assurance systems } \\
\text { Policy enactment } \\
\text { Addressing the self in } \\
\text { research }\end{array}$ & Education policies \\
\hline $\begin{array}{l}\text { Collaboration } \\
\text { Motivation } \\
\text { Research/teaching divide } \\
\text { Self-reflection } \\
\text { Collective* } \\
\text { Narratives } \\
\text { Authority }\end{array}$ & $\begin{array}{l}\text { Professionalism } \\
\text { Reflective communities } \\
\text { Identity construction } \\
\text { Professional learning } \\
\text { Conflicting professional roles }\end{array}$ & $\begin{array}{l}\text { Professional } \\
\text { development }\end{array}$ \\
\hline
\end{tabular}




\begin{tabular}{|c|c|c|}
\hline Support & & \\
\hline $\begin{array}{l}\text { Self-discipline } \\
\text { Surveillance } \\
\text { Discourse* } \\
\text { Emotional labor } \\
\text { Critical consciousness* } \\
\text { Professional identity renegotiation* } \\
\text { Ideology } \\
\text { Sexism } \\
\text { Race } \\
\text { Diversity }\end{array}$ & $\begin{array}{l}\text { Professional identity } \\
\text { Cultural identity } \\
\text { Racial identity } \\
\text { Gender identity }\end{array}$ & Identity \\
\hline $\begin{array}{l}\text { Awareness* } \\
\text { Change } \\
\text { Writing } \\
\text { Feminist } \\
\text { Power }\end{array}$ & $\begin{array}{l}\text { Critical pedagogy } \\
\text { Cultural awareness } \\
\text { Multiple identities } \\
\text { Ethics of care }\end{array}$ & Social justice \\
\hline
\end{tabular}

* Codes associated with more than one theme

Table 3. Themes and sub-themes per article

\begin{tabular}{|l|l|l|}
\hline Authors & Sub-themes & Themes \\
\hline Baker et al. (2016) & I & $\begin{array}{l}\text { Education } \\
\text { policies }\end{array}$ \\
Newcomer \& Collier (2015) & SJ & SJ (2017)
\end{tabular}


University Teacher Educators' Professional Agency

\begin{tabular}{|c|c|c|}
\hline Bourke et al. (2018) & PD & \\
\hline Cross et al. (2018) & SJ, EP & \\
\hline Ellis et al. (2014) & & \\
\hline Solbrekke \& Sugrue (2014) & & \\
\hline Henning et al. (2018) & SJ & \\
\hline Bronkhorst et al. (2013) & 1 & \multirow{10}{*}{$\begin{array}{l}\text { Professional } \\
\text { development }\end{array}$} \\
\hline Hökkä et al. (2017) & I, EP & \\
\hline Liu \& Ye (2019) & 1 & \\
\hline Edwards-Groves (2013) & I, EP & \\
\hline Leibowitz et al. (2012) & 1 & \\
\hline Mandikonza \& Lotz-Sisitka (2016) & SJ EP & \\
\hline Roberts \& Weston (2914) & 1 & \\
\hline Yazan (2018) & 1 & \\
\hline Yuan \& Lee (2014) & 1 & \\
\hline Taylor et al. (2014) & 1 & \\
\hline Harris (2011) & SJ, EP & \multirow{5}{*}{ Identity } \\
\hline Trent (2013) & PD & \\
\hline Hökkä \& Vähäsantanen (2014) & $P D, E P$ & \\
\hline Hökkä \& Eteläpelto (2014) & $P D, E P$ & \\
\hline Hökkä et al. (2012) & & \\
\hline Urrieta \& Méndez & I, EP & \multirow[b]{3}{*}{ Social justice } \\
\hline Shealey et al. (2014) & 1 & \\
\hline Black et al. (2017) & I, EP & \\
\hline
\end{tabular}




\begin{tabular}{|l|l|l|} 
Gallavan \& Webster-Smith (2012) & PD & \\
Halai \& Durrani (2018) & I, EP & \\
\hline
\end{tabular}

EP: Education policies

PD: Professional development

I: Identity

SJ: Social Justice

\section{Education policies}

Eight out of 28 articles reported findings on the effects of education policies on TEs' achievement of professional agency within their working contexts. Following global HE trends, where financial imperatives shape learning and teaching decision-making, the topdown implementation of e-learning in Arts education affected Australian TEs' professional identities and perceptions of agency (Baker, Hunter \& Thomas, 2016). Underpinned by activity theory, the proletarianization of TEs by their institutions' denial of opportunities to accumulate academic capital (research publications, grants) revealed the complex relationships between individual agency and the British $\mathrm{HE}$ value system that prioritized research (Ellis, McNicholl, Blake \& McNally, 2014).

Along with state-mandated Teacher Performance Assessments (TPAs) in the US, came TEs' difficulties to implement them in ITE programs. By story-telling and collaborative reflection, four TEs researched the effects of TPAs on their justice-oriented agency, while keeping committed to educating pre-service teachers to meet and resist the demands of standardized testing (Henning, Dover, Dotson \& Agarwal-Rangnath, 2018). Aligned to feminist research, a group of TEs used collective art-based poetic inquiry to address their emotional experiences - from despair and resignation to agency and empowerment-when confronting high-stakes testing and standardization of ITE, contrary to their social justice commitments (Cross, Dunn \& Dotson, 2018). Another study detailed how the actions by special education teacher education programs to appropriate TPAs enhanced or weaken TEs' participation, democracy and agency (Bartlett, Otis-Wilborn \& Peters, 2017).

Neoliberal policy changes and prescriptions to ITE were contrasted with TEs' accounts of transformed, but not undermined, professional agency. Solbrekke \& Sugrue (2014) and Bourke, Ryan \& Ould (2018) investigated the agentic practices of Irish and Australian TEs, working under the pressures of accountability, professional standards, and accreditation processes. Similarly, Newcomer \& Collier (2015) explored American TEs' interpretation of 
new language education policy, and its implementation through their classroom practice in ways they believed were best for their students.

\section{Professional development}

Ten studies examined the close link between TEs' professional development and agency. Shared learning and collaborative analytical dialogue within professional communities empowered TEs' collective agency and identity and counteracted the effects of managerial governance on professionalism (Edwards-Groves, 2013; Hökkä, Vähäsantanen \& Mahlakaarto, 2017). And collaboration between Dutch TEs and educational researchers fostered TEs' individual and collective agency in an intervention research, where everybody took the role of a researcher and learner (Bronkhorst, Meijer, Koster, Akkerman \& Vermunt, 2013). Additionally, a collaborative self-study with school mentors investigated the tensions between individual and collective agency for university TEs and mentors, working together as co-educators, and the value of professional development in communal spaces (Taylor, Klein \& Abrams, 2014).

Also, the need for contextually sensitive professional development, positively influencing professional agency, was emphasized. Meaningful professional development enhanced TEs' agency and identity negotiations, maximizing their professional self-worth while counteracting a research-intensive institutional culture that undervalued teaching (Leibowitz, van Schalkwyk, Ruiters, Farmer \& Adendorff, 2012). Roberts \& Weston (2014) analyzed the intersection of professional development, identity and agency in an academic writing support program, and its positive effects on TEs' sense of professional self since it addressed professional learning instead of the explicit demand for publications. And Mandikonza \& Lotz-Sisitka (2016) detailed the enhancement of South African TEs' agency and reflexive practice by an initiative to develop professional competencies for environmental and sustainability education. Yet, the opposite case of lack of professional development support could also happen, as demonstrated by TEs in Hong Kong, struggling to cope with the demands of the "publish or perish" culture, and bridge the researcherpractitioner divide (Yuan \& Lee, 2014).

Because professional development may involve the exchange of roles and tasks, its success would depend upon TEs' progressive agency to delve into and renew their professional identities. This is the case of Yazan's (2018) self-study, who explored his identity construction, and efforts to assert agency and self-development in the quest for the necessary growth of pedagogical knowledge. While Liu \& Ye (2019) examined the Confucian practice of ren-de agency as a form of professional agency helping Chinese TEs, engaged in international professional development, overcame the challenges of integrating their global and local (glocal) identities and experiences abroad and upon returning home. 


\section{Identity}

Five articles addressed the role of TEs' professional agency in weaving together the different strands of identity-racial, religious, gender and professional-into a complex but dynamic fabric at their work settings. The more agency they achieved at work, the more successful they were at their identity renegotiations. Thus, Trent (2013) detailed novice language TEs' transitions from schoolteacher to university teacher educators in Hong Kong; their learning opportunities and conflicting experiences of identity reconstruction. Furthermore, studies were focused on Finnish TEs' achievement of individual and collective agency to negotiate their professional and sometimes conflicting identities, enhance their professional learning and promote organizational change within their working contexts (Hökkä \& Eteläpelto, 2014; Hökkä, Eteläpelto \& Rasku-Puttonen, 2012; Hökkä, \& Vähäsantanen, 2014). Finally, Harris (2011) reported white TEs' dilemmas of preparing teachers for a culturally diverse world at an American Christian university, affecting their professional identity and agency. Framed by Foucauldian ideas of disciplinary power, her findings revealed their self-discipline and self-censorship practices under institutional surveillance, especially when discussing racial identity and racism in a predominantly white institution.

\section{Social justice}

Social justice was the main theme in five papers exploring TEs' embrace of their change agent roles within (and despise) the institutional framework of their workplaces. Such was the case of Black, Crimmins \& Henderson's (2017) autoethnographic space of voice and agency to discuss gender inequity and the culture of the neoliberal university affecting their lives in Australia. Similarly, studies addressed the confluence of racial identity, ethnicity and gender, and TEs' agency to resist, subvert, and challenge the white normativity of academia in the US, contributing to the cause of social justice (Shealey, McHatton, McCray \& Thomas, 2014; Urrieta \& Mendéz, 2007). The development of cultural competence as a journey that enriched TEs' sense of professional agency was traced by Gallavan \& Webster-Smith (2012) in a self-study and action research. But how do TEs model social justice in their classes? Halai \& Durrani (2018) answered this question by analyzing TEs' construction of national identity, and the promotion of peacebuilding in Pakistani conflict-affected zones. Their evidence revealed that TEs relegated social cohesion to the peripheral curriculum of their programs, despite understanding its relevance.

\section{Discussion}

This scoping review maps the multiple factors involved in the achievement of university TEs' professional agency at work. Depending on how they interrelate, these factors (e.g., professional standards or the researcher versus practitioner identity divide) offer opportunities or constraints for the emergence of different modes of agency (e.g., collective, reserved or progressive). In the thematic analysis, they organized themselves in four interconnected themes (figure 2). Hence, education policies are overarching across 
most of the studies while professional development is vital to sustaining professional identity, and constructing a strong identity is critical to efforts to teach for social justice.

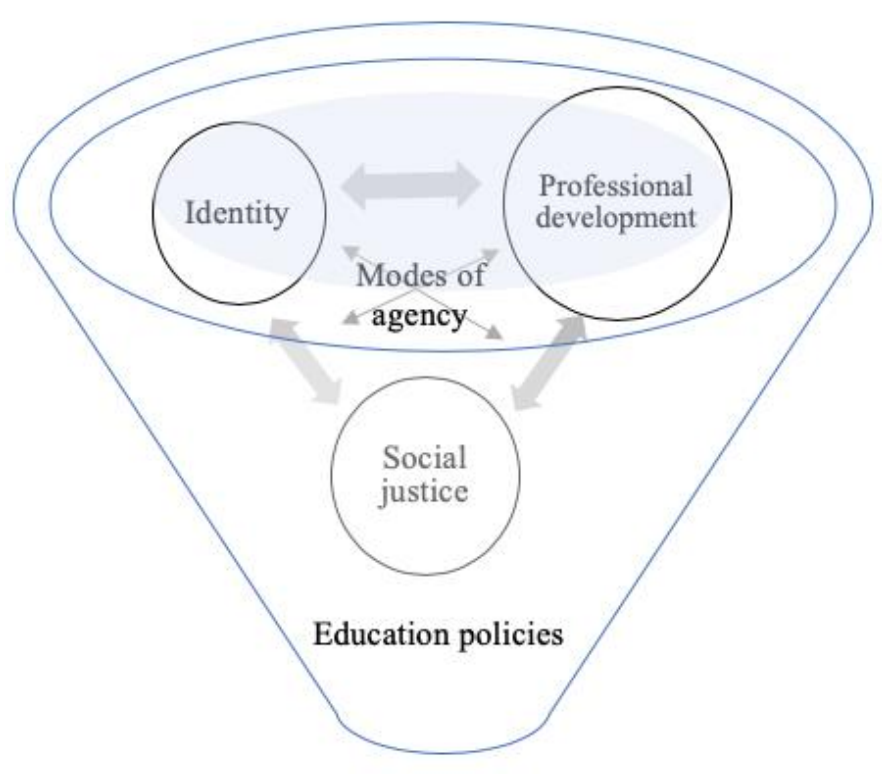

Figure 2. Thematic representation

Teacher education has traditionally suffered from low status within academia (Laberee, 2008). Then, it is unsurprising that the managerial mindset of productivity and performativity in ITE and HE policies affects TEs' professionalism. It challenges their professional development, undermines their professional identity, and hinders or makes more urgent their action for social justice and change. But if the theme of education policies shows how their implementation and top-down controls and prescriptions condition TEs' work, it also reveals that structural change brings the potential for agency achievement.

Following the ecological perspective on agency, it could be argued that the findings suggest that TEs are as much "able to be reflexive and creative," acting counter to the structural constraints of education reform, as "enabled and constrained" by their contextual and biographical factors (Priestley et al., 2015, p. 22). Hence, despite being precarized by discourses of competitiveness, performativity and academic capitalism (Ellis et al., 2014), they find spaces for expressing their emotions, and engaging in critically reflective dialogue and writing that enhance professional agency (Cross et al., 2018; Henning et al., 2018). For TEs, language becomes a creative tool to achieve agency in their professional lives, challenging and resisting their working environments and conditions collectively. Here, overlapping with professional development and social justice issues, they exercise reflexivity and collaboration in taking responsibility for their agency and driving change. This is pretty much in line with Archer's (2000) view that articulating shared interests, organizing for 
collective action, and exercising collaborative decision-making may realize corporate agency.

Opportunities for strong or reserved agency are found in the reviewed studies. Entwined with TEs' interests, assumptions and experiences, they enable them (more or less successfully) to adjust policy requirements to their beliefs and values to safeguard their agency in their contexts of practice. Thus, the constraints of education policies and quality assurance regimes can open TEs possibilities for strong or reserved agency through innovative teaching with a culturally relevant pedagogy; creative compliance to performance management demands to keep autonomy and responsibility; or active resistance through policy reification to make it viable in teaching settings (Bartlett et al., 2017; Bourke et al., 2018; Newcomer \& Collier, 2015; Solbrekke \& Sugrue, 2014). In these studies, neither professional agency can be separated from the dynamics of power nor from individuals' career stages, experiences and beliefs.

Concerning macro- (government) and meso- (institution) levels, TEs achieve weak agency when acting upon major reform or institutional policy decisions but strong agency at the micro-level, in their responses to imposed change through their teaching practices. Connected to the theme of professional identity, the findings from Baker et al. (2016) indicate that broader ITE reforms trigger TEs' ambivalence, resistance, a sense of eroded agency and considerable difficulty in identity renegotiations. Such findings are aligned to Vähäsantanen's (2015) assertion that professional agency can reveal itself through maintainable to transformative actions when negotiating professional identity. Either educational change is a factor influencing TEs' renegotiation of their identities or is insufficient to trigger identity renewal. These studies make the case for considering fostering TEs' appropriation of policy through participatory and democratic policy-making, which turns weak and reserved professional agency into strong and progressive through a more bottom-up approach to education reform. Nevertheless, in the studies above, education policy discourse and practice manifest a limited understanding of what enhances TEs' professional identity and agency.

Here professional development is inextricably linked to education policies and identity, providing a lens to understand their relationship with professional agency. As universities must fulfil the requirements of HE and ITE policies, TEs are left with one foot in the academia and the other in the realm of professional practice. In the review, an identified challenge is creating professional development that gives them opportunities to balance autonomous practice with mandates of standardization and quality assurance, face the demands of international mobility and scholar productivity, or agentically delve into and renew professional identities (Leibowitz et al., 2012; Liu \& Ye, 2019; Roberts \& Weston, 2014; Yazan, 2018; ). Otherwise, without spaces for effective professional development, TEs may feel at lost navigating the tensions of conflicting identities and increasing scholar research and teaching demands (Yuan \& Lee, 2014). 
As Loughran (2014) recommends, to make professional development meaningful, TEs must be afforded agency to bring their vision of what they need to learn into deliberately conceptualized opportunities to advance their knowledge and expertise. Giving them individual or collective ownership of the purpose of their learning processes is a condition for their agency to shape and being shaped by professional development. The findings suggest that professional development, nurturing individual and collective agency, helps TEs step out of professional isolation, interrogate the audit and performative culture of their workplaces, carve out a space to regain professional responsibility and autonomy, and create new possibilities for professionalism (Bronkhorst et al., 2013; Edwards-Groves, 2013; Hökkä et al., 2017; Taylor et al., 2014). And by engaging in collaborative professional learning communities and critical reflection, they develop the stance and knowledge needed to become agents of change in the educational or broader societal landscape (Mandikonza \& Lotz-Sisitka, 2016).

Certainly, agency in academia is not only rooted in "the freedom to make, think and speak but significantly the freedom to ask why, to disagree, disrupt, and transform" (Gale, 2019, p. 6). Intersecting with issues of identity, the theme of social justice illustrates how TEs strive to achieve agency for change and social justice despise the constraints of institutional practices and socio-cultural beliefs, imbuing their teaching and research with ethical, moral and social dimensions. Thus, located in a particular "deficit-othered" position-ethnic, racial minority or female-TEs may find balancing research, teaching and service more challenging than their white peers, even more so when they attempt to instill social justice and multiculturality in their professional practices (Shealey et al., 2014; Urrieta \& Méndez, 2007). But their agency-as-resistance allows them to oppose and reject confinement and self-subjugation within predetermined discourses of power and knowledge (Foucault, 1980), being implicitly functional to identity and social justice.

In Gallavan \& Webster-Smith (2012) and Black et al. (2017), feeling the power of their critical voices is vital for TEs to develop a sense of agency, and position themselves as change agents in and out their professional spaces. Such stories illuminate the confluence of professional agency and diverse identities. They also highlight how TEs oppose the promotion of neoliberal agency, and its values of individualism and entrepreneurialism, through collectives, collaboration and critical consciousness. But notions of social justice are closely tied to individual perspectives, specific sociocultural and sociopolitical contexts that cannot be ignored, defying any reductionist attempt to define it (Halai \& Durrani, 2018). Moreover, TEs' subjectivities and intersectional identities, especially in terms of race, gender and religion, are crucial to understanding how agency is achieved within their particular contexts.

The overlap of identity with social justice and education policies further problematizes the achievement of TEs' professional agency. On one hand, although their professional identity is grounded on the recognition that they are agents of choice within their professional 
communities, the structural conditions of their transformation-resistant institutions contradict their efforts for culturally sensitive and inclusive pedagogy (Harris, 2011). On the other, they still achieve agency when making choices to craft their identities, despite the pressures of managerial imperatives forcing them to be passive implementers of top-down driven change (Hökkä et al., 2012; Hökkä \& Eteläpelto, 2014; Hökkä, \& Vähäsantanen, 2014). Also, findings (Trent, 2013) highlight the centrality of agency in novice TEs' complex identity reconstruction, adjustment to a new work environment, and the alleviation of their fear of research (especially when they may primarily identify themselves as teachers). TEs' awareness of their agency is vital to renew their identities, and successfully position themselves within their professional and academic communities.

The four themes compose a fabric of interconnected factors, presenting opportunities and constraints for TEs' achievement of different modes of professional agency, which cannot be reduced to the aggregation of individual agentic capabilities. When education policies promote managerial and marketized types of governance in HE and ITE, undermining the ethical and professional dimensions of university TEs' work, structural constraints can become opportunities for agency. Extending the anchoring definition of TEs' professional agency for this review (Hökka et al., 2012), it can be said that, as social settings and working conditions pose challenges to their agency achievement, they are also critical in molding the types of agency that sustain their identities while confronting such challenges. As they are positioned and position themselves at temporal and social contexts defining their possibilities of action, such modes of professional agency unfold when TEs carve out opportunities for adapting, resisting and contesting the dominant culture of metrics, quality assurance and academic capitalism. Collectively or individually, through teaching practices, meaningful professional development, learning communities and qualitative researchwhere personal experiences become central focus and resource of enquiry-university TEs do not succumb to the performative effect of neoliberal agency in HE. And by doing so, they strive to engage in humanizing pedagogy and research that question neoliberal values in education and empower them as agents for social justice and change.

\section{Agenda for future research}

Meeting the inclusion criteria of this scoping review, the 28 selected studies reflect the paucity of research focusing primarily on the subject. Furthermore, the selected studies show little emphasis on the close connection between TEs' emotions, professional agency and institutional dynamics. From a sociological standpoint, future research could clarify the role of emotions in agentic interactions at social micro-levels, and their effects on meso- and macro-level structures. Also, since the review illustrates the relevance of self-study and autoethnography in exploring agency, further research could examine the significance of critical reflexive practice in nurturing individual and collective professional agency. Although the importance of communities of learning is not underestimated in the current literature, research could be fostered to better understand how they enhance the achievement of TEs' 
professional agency and their professional development. Questions remain unanswered on the interplay between individual and collective agency; for example, how TEs' agency is achieved in specific classroom contexts, and how it operates when they are members of collectivities. There is also scope for research regarding the impact of ICT and digital technology on TEs' agency. Identifying how technology influences educational reform and, subsequently, TEs' agency could contribute to a better understanding of the possibilities for enhancing their creativity and innovation within professional spaces in rapid digital transformation.

Further research could examine the tensions that the market principle of "student as consumer" brings to TEs' agency, working under regimes of measurement of students' satisfaction. The "potential splitting between teachers' own judgements about 'good practice' and students' 'needs' and the rigors of performance" (Ball, 2003, p.221) destabilizes TEs' scope for agency, being pressed into performativity and compliance to meeting the demands of a customer service model. Against the background of a discourse positioning students as customers, it would be beneficial to explore the possibilities that such discourse offers to TEs as change agents. Moreover, how TEs (re)shape their agency under the influence of the relationships with student-teachers may need further examination. The dynamics associated with their interactions could be considered for a thorough understanding of what agency means in ITE, and how they should support the achievement of their student-teachers' agency.

Since the small number of participants in the yielded studies (16 have six or fewer), much of what can be claimed as known about TEs is context- and subject-specific, precluding the possibility of general claims, and challenging the long-term maturation of the field of research on agency. This is not to question the value of qualitative studies with few participants, but to suggest that mixed-method studies could be crucially informing common issues of TEs' professional agency in diverse institutional or cultural settings, through smaller-scale subject or context-specific studies. Hence, quantitative methods could help examine the complexity of the interplay between agency and relational structures (e.g., whether changes in perceptions precede or follow changes in practices), while qualitative methods could capture the nature of context-embedded inclusive practices (e.g., with a smaller sample of participants). Considering the dynamism of TE's professional agency, longitudinal designs could research the conditions influencing its achievement through their career stages, or those in which TEs tend to act as agents of change.

\section{Limitations}

One limitation of this review is that only English-speaking publications were included and most of these originated within Western developed countries, limiting its generalizability. Therefore, the effects of cultural and social differences must be acknowledged. Another limitation arises from including only articles published in peer-reviewed journals, excluding a significant body of knowledge contained in conference papers, dissertations, theses, and 
book chapters. Finally, samples in the studies were small and thus findings are contextuallybound and may not apply to other settings. Examining the reference list of the selected publications and performing trial searches helped to mitigate these limitations.

\section{Conclusion}

This scoping review synthesizes research on university TEs' professional agency, mapping four salient themes from literature: education policies, professional development, social justice, and identity. The themes intersect in most studies, forming the basis for identification of the factors-opportunities and constraints-involved in TEs' achievement of professional agency. English-language research on this field has grown in the last decade, yet it remains sparse and limited to national contexts. Strengthening international networks of TEs and researchers may facilitate the implementation of cross-cultural research and should contribute to better understandings of their agency amidst heterogeneous sociocultural and institutional contexts. Greater exchange and promotion of knowledge could help stakeholders, such as policymakers and HE academic leaders, to recognize and develop effective conditions to strengthen the profession of TEs and enhance ITE programs.

\section{Article history}

Received: 08 Oct 2019

Accepted: 18 Mar 2020

Published: XX Jun 2020

\section{References}

Alvesson, M., Ashcraft, K. L., \& Thomas, R. (2008). Identity matters: Reflections on the construction of identity scholarship in organization studies. Organization, 15(1), 528. https://doi.org/10.1177/1350508407084426

Archer, M. (2000). Being human: The problem of agency. Cambridge: Cambridge University Press. https://doi.org/10.1017/CBO9780511488733

Archer, M. (2003). Structure, agency, and the internal conversation. Cambridge: Cambridge University Press. https://doi.org/10.1017/CBO9781139087315

Arksey, H., \& O'Malley, L. (2005). Scoping studies: Towards a methodological framework. International Journal of Social Research Methodology, 8(1), 19-32. https://doi.org/10.1080/1364557032000119616

Avis, J., \& Reynolds, C. (2018). The digitalization of work and social justice: Reflections on the labour process of English further education teachers. In C. Harteis (Ed.), The impact of digitalization in the workplace: Professional and practice-based learning (pp. 213-229). Dordrecht: Springer. https://doi.org/10.1007/978-3-319-63257-5 14

Baker, W. J., Hunter, M. A., \& Thomas, S. (2016). Arts education academics' perceptions of eLearning \& teaching in Australian early childhood and primary ITE degrees. 
University Teacher Educators' Professional Agency

Australian Journal of Teacher Education, 41(11), 31-43.

http://dx.doi.org/10.14221/ajte.2016v41n11.3

Ball, S. J. (2003). The teacher's soul and the terrors of performativity. Journal of Education Policy, 18(2), 215-228. https://doi.org/10.1080/0268093022000043065

Bandura, A. (2001). Social cognitive theory: An agentic perspective. Annual Review of Psychology, 52(1), 1-26.https://doi.org/10.1111/1467-839X.00024

Barker, C. (2003). Cultural studies: Theory and practice. United States: Sage Publications.

Bartlett, M., Otis-Wilborn, A., \& Peters, L. (2017). Bending or breaking: Appropriating edTPA policy in special education teacher education. Teacher Education and Special Education, 40(4), 287-298. https://doi.org/10.1177/0888406417720188

Ben-Peretz, M. (2001). The impossible role of teacher educators in a changing world. Journal of Teacher Education, 52(1), 48-56. https://doi.org/10.1177/0022487101052001005

Biesta, G.J.J., \& Tedder, M. (2007). Agency and learning in the lifecourse: Towards an ecological perspective. Studies in the Education of Adults, 39(2), 132-149. https://doi.org/10.1080/02660830.2007.11661545

Black, A. L., Crimmins, G., \& Henderson, L. (2017). Positioning ourselves in our academic lives: Exploring personal/professional identities, voice and agency. Discourse: Studies in the Cultural Politics of Education, 40(4), 530-544. https://doi.org/10.1080/01596306.2017.1398135

Bourke, T., Ryan, M., \& Ould, P. (2018). How do teacher educators use professional standards in their practice? Teaching and Teacher Education, 75, 83-92. https://doi.org/10.1016/i.tate.2018.06.005

Bronkhorst, L. H., Meijer, P. C., Koster, B., Akkerman, S. F., \& Vermunt, J. D. (2013). Consequential research designs in research on teacher education. Teaching and Teacher Education, 33, 90-99. https://doi.org/10.1016/i.tate.2013.02.007

Clarke, L., \& McFlynn, P. (2019). All animals learn, but only humans teach: The professional place of teacher educators. Education Sciences, 9(3), 192. https://doi.org/10.3390/educsci9030192

Cobb, D. J., \& Couch, D. (2018). Teacher education for an uncertain future: Implications of PISA's Global Competence. In D. Heck, \& A. Ambosetti (Eds.), Teacher education in and for uncertain times (pp. 35-47). Singapore: Springer.

https://doi.org/10.1007/978-981-10-8648-9 3

Cochran-Smith, M. (2003). Learning and unlearning: The education of teacher educators. Teaching and Teacher Education, 19(1), 5-28. https://doi.org/10.1016/S0742$\underline{051 \times(02) 00091-4}$ 
Cross, S. B., Dunn, A. H., \& Dotson, E. K. (2018). The intersections of selves and policies: A poetic inquiry into the hydra of teacher education. Education Policy Analysis Archives, 26, 29. http://dx.doi.org/10.14507/epaa.26.2813

Davey, R. (2013). The professional identity of teacher educators: Career on the cusp? Abingdon, Oxfordshire: Routledge. https://doi.org/10.4324/9780203584934

Edwards, A. (2005). Relational agency: Learning to be a resourceful practitioner. International Journal of Educational Research, 43(3),168-182. https://doi.org/10.1016/i.ijer.2006.06.010

Edwards-Groves, C. J. (2013). Creating spaces for critical transformative dialogues: Legitimising discussion groups as professional practice. Australian Journal of Teacher Education, 38(12). http://dx.doi.org/10.14221/ajte.2013v38n12.1

Ellis, V., McNicholl, J., Blake, A., \& McNally, J. (2014). Academic work and proletarianisation: A study of higher education-based teacher educators. Teaching and Teacher Education, 40, 33-43. https://doi.org/10.1016/i.tate.2014.01.008

Emirbayer, M., \& Mische, A. (1998). What is agency? American Journal of Sociology, 103(4), 962-1023. https://www.jstor.org/stable/10.1086/231294

Eteläpelto, A., Vähäsantanen, K., Hökkä, P., \& Paloniemi, S. (2013). What is agency? Conceptualizing professional agency at work. Educational Research Review, 10, 4565. https://doi.org/10.1016/i.edurev.2013.05.001

Forsman, P., Collin, K., \& Eteläpelto, A. (2014). The practice of professional agency and the emergence of collaborative creativity in developmental staff meetings. In C. Harteis, A. Rausch, \& J. Seifried (Eds.), Discourses on professional learning: Professional and practice-based learning (pp. 45-74). Dordrecht: Springer.

https://doi.org/10.1007/978-94-007-7012-6 4

Foucault, M. (1980). Power/knowledge: Selected interviews and other writings 1972-1977. New York: Pantheon Books.

Gale, C. (2019, September). Polyphonic praxis: Towards a collective turn in design pedagogy and practice. Paper Presented at the International Association of Societies of Design Research Conference 2019. Manchester Metropolitan University. Retrieved from https://iasdr2019.org/uploads/files/Proceedings/vo-f-1087-Gal C.pdf

Gallavan, N. P., \& Webster-Smith, A. (2012). Cultural competence and the recursive nature of conscientization. Action in Teacher Education, 34(5-6), 401-419. https://doi.org/10.1080/01626620.2011.627049

Gershon, Ilana. 2011. “Neoliberal Agency.” Current Anthropology, 52(4), 537-555. https://www.jstor.org/stable/10.1086/660866

Giddens, A. (1984). The constitution of society. Berkeley: University of California Press. 
Halai, A., \& Durrani, N. (2018). Teachers as agents of peace? Exploring teacher agency in social cohesion in Pakistan. Compare: A Journal of Comparative and International Education, 48(4), 535-552. https://doi.org/10.1080/03057925.2017.1322491

Harris, G. (2011). Teacher educators under surveillance at a religious university. Teachers and Teaching, 17(5), 545-558. https://doi.org/10.1080/13540602.2011.602208

Henning, N., Dover, A. G., Dotson, E. K., \& Agarwal-Rangnath, R. (2018). Storying teacher education policy: Critical counternarratives of curricular, pedagogical, and activist responses to state-mandated teacher performance assessments. Education Policy Analysis Archives, 26, 26. http://dx.doi.org/10.14507/epaa.26.2790

Hökkä, P., Eteläpelto, A., \& Rasku-Puttonen, H. (2012). The professional agency of teacher educators amid academic discourses. Journal of Education for Teaching, 38(1), 83102. https://doi.org/10.1080/02607476.2012.643659

Hökkä, P., \& Eteläpelto, A. (2014). Seeking new perspectives on the development of teacher education: A study of the Finnish context. Journal of Teacher Education, 65(1), 39-52. https://doi.org/10.1177/0022487113504220

Hökkä, P., \& Vähäsantanen, K. (2014). Agency-centred coupling-a better way to manage an educational organization? International Journal of Leadership in Education, 17(2), 131-153. https://doi.org/10.1080/13603124.2013.783932

Hökkä, P., Vähäsantanen, K., \& Mahlakaarto, S. (2017). Teacher educators' collective professional agency and identity-Transforming marginality to strength. Teaching and Teacher Education, 63, 36-46. https://doi.org/10.1016/i.tate.2016.12.001

Ibarra, H. (1999). Provisional selves: Experimenting with image and identity in professional adaptation. Administrative Science Quarterly, 44(4), 764-

91. https://doi.org/10.2307/2667055

Isotalo, S. (2017). Teacher educators' professional identity formation in a challenging context: Experience from Eritrea (Master's thesis, University of Jyväskylä, Finland). Retrieved from http://urn.fi/URN:NBN:fi:jyu-201706082749

Ipkeze, C. H. (2016). The blended course design: The role of agency in a pedagogical shift. Enacting Self-study as Methodology for Professional Inquiry, 11, 463-469. Retrieved from https://fisherpub.sjfc.edu/education facpub/61/

Izadinia, M. (2014). Teacher educators' identity: A review of literature. European Journal of Teacher Education, 37(4), 426-441. https://doi.org/10.1080/02619768.2014.947025

Joffe, H. (2012). Thematic Analysis. In D. Harper, \& A. R. Thompson (Eds.), Qualitative research methods in mental health and psychotherapy: A guide for students and practitioners (pp. 209-223). Chichester: Wiley.

https://doi.org/10.1002/9781119973249.ch15 
Ketschau, T.J. (2015). Social justice as a link between sustainability and educational sciences. Sustainability, 7(11), 15754-15771. https://doi.org/10.3390/su71115754

Laberee, D. F. (2008). An uneasy relationship: The history of teacher education in the university. In M. Cochran-Smith, S. Feiman-Nemser, \& J. McIntyre (Eds.), Handbook of research on teacher education: Enduring questions in changing contexts (3rd ed.). Washington, DC: Association of Teacher Educators.

Leibowitz, B., van Schalkwyk, S., Ruiters, J., Farmer, J., \& Adendorff, H. (2012). "It's been a wonderful life": Accounts of the interplay between structure and agency by "good" university teachers. Higher Education, 63(3), 353-

365. https://doi.org/10.1007/s10734-011-9445-8

Levac, D., Colquhoun, H., \& O'Brien, K. K. (2010). Scoping studies: Advancing the methodology. Implementation Science, 5(69), 1-9. https://doi.org/10.1186/1748$\underline{5908-5-69}$

Lipponen, L., \& Kumpulainen, K. (2011). Acting as accountable authors: Creating interactional spaces for agency work in teacher education. Teaching and Teacher Education, 27(5), 812-819. https://doi.org/10.1016/i.tate.2011.01.001

Liu, L. B., \& Ye, J. (2019). Ren-de agency in international faculty professional development: A China case study of glocal identity integration. Teacher Development, 23(4), 447-468. https://doi.org/10.1080/13664530.2019.1611628

Loughran, J. (2014). Professionally developing as a teacher educator. Journal of Teacher Education, 65(4), 271-283. https://doi.org/10.1177/0022487114533386

Lunenberg, M., Dengerink, J., \& Korthagen, F. (2014). The professional teacher educator: Roles, behaviour, and professional development of teacher educators. Rotterdam: Sense Publishers. https://doi.org/10.1007/978-94-6209-518-2

Mandikonza, C., \& Lotz-Sisitka, H. (2016). Emergence of environment and sustainability education (ESE) in teacher education contexts in southern Africa: A common good concern. Educational Research for Social Change, 5(1), 107-130.

https://doi.org/10.17159/2221-4070/2016/v5i1a7

McEvoy, E., MacPhail, A., \& Heikinaro-Johansson, P. (2015). Physical education teacher educators: A 25-year scoping review of literature. Teaching and Teacher Education, 51, 162-181. https://doi.org/10.1016/i.tate.2015.07.005

Newcomer, S. N., \& Collier, L. C. (2015). Agency in action: How teachers interpret and implement Arizona's 4-hour structured English immersion program. International Multilingual Research Journal, 9(3), 159-176. https://doi.org/10.1080/19313152.2015.1048179

Pantić, N., \& Florian, L. (2015). Developing teachers as agents of inclusion and social justice. Education Inquiry, 6(3), 27311. https://doi.org/10.3402/edui.v6.27311 
Ping, C., Schellings, G. L. M., \& Beijaard, D. (2018). Teacher educators' professional learning: A literature review. Teaching and Teacher Education, 75, 93-104. https://doi.org/10.1016/i.tate.2018.06.003

Priestley, M., Biesta, G.J.J., \& Robinson, S. (2015). Teacher agency: What it is and why it matters. In J. Evers \& R. Kneyber (Eds.), Flip the system: Changing education from the ground up. London: Routledge. https://doi.org/10.4324/9781315678573-15

Roberts, A., \& Weston, K. (2014). Releasing the hidden academic? Learning from teachereducators' responses to a writing support programme. Professional Development in Education, 40(5), 698-716. https://doi.org/10.1080/19415257.2013.835277

Samuelsson, K. (2018). Teacher collegiality in context of institutional logics: A conceptual literature review. Professions and Professionalism, 8(3). https://doi.org/10.7577/pp.2030

Shealey, M. W., McHatton, P. A., McCray, E., \& Thomas, U. (2014). "Sista Doctas" taking a seat at the table: Advocacy and agency among women of colour in teacher education. NASPA Journal about Women in Higher Education, 7(1), 19-46. https://doi.org/10.1515/njawhe-2014-0003

Solbrekke, T. D., \& Sugrue, C. (2014). Professional accreditation of initial teacher education programmes: Teacher educators' strategies-Between 'accountability' and 'professional responsibility'? Teaching and Teacher Education, 37, 11-20. https://doi.org/10.1016/i.tate.2013.07.015

Taylor, M., Klein, E. J., \& Abrams, L. (2014). Tensions of reimagining our roles as teacher educators in a third space: Revisiting a co/autoethnography through a faculty lens. Studying Teacher Education, 10(1), 3-19. https://doi.org/10.1080/17425964.2013.866549

Thomas, J., \& Harden, A. (2008). Methods for the thematic synthesis of qualitative research in systematic reviews. BMC Medical Research Methodology, 8(1), 45. https://doi.org/10.1186/1471-2288-8-45

Trent, J. (2013). Becoming a teacher educator: The multiple boundary-crossing experiences of beginning teacher educators. Journal of Teacher Education, 64(3), 262275. https://doi.org/10.1177/0022487112471998

Urrieta Jr, L., \& Méndez Benavidez, L. R. (2007). Community commitment and activist scholarship: Chicana/o professors and the practice of consciousness. Journal of Hispanic Higher Education, 6(3), 222-236. https://doi.org/10.1177/1538192707302535

Vanassche, E., \& Kelchtermans, G. (2015). The state of the art in self-study of teacher education practices: A systematic literature review. Journal of Curriculum Studies, 47(4), 508-528. https://doi.org/10.1080/00220272.2014.995712 
University Teacher Educators' Professional Agency

Vähäsantanen, K. (2015). Professional agency in the stream of change: Understanding educational change and teachers' professional identities. Teaching and Teacher Education, 47, 1-12. http://dx.doi.org/10.1016/i.tate.2014.11.006

Vygotsky, L. S. (1978). Mind in society: The development of higher psychological processes. Cambridge, MA: Harvard University Press.

White, E., Dickerson, C., \& Weston, K. (2015). Developing an appreciation of what it means to be a school-based teacher educator. European Journal of Teacher Education, 38(4), 445-459. https://doi.org/10.1080/02619768.2015.1077514

Wilson, E., \& Deaney, R. (2010). Changing career and changing identity: How do teacher career changers exercise agency in identity construction? Social Psychology of Education, 13(2), 169-183. https://doi.org/10.1007/s11218-010-9119-x

Yazan, B. (2018). TESL Teacher Educators' Professional Self-Development, Identity, and Agency. TESL Canada Journal, 35(2), 140155. https://doi.org/10.18806/tesl.v35i2.1294

Yuan, R., \& Lee, I. (2014). Understanding language teacher educators' professional experiences: An exploratory study in Hong Kong. The Asia-Pacific Education Researcher, 23(1), 143-149. https://doi.org/10.1007/s40299-013-0117-6 